\title{
The Design Of Resort Hotel In Tuktuk (Neo-Vernacular Architecture)
}

\author{
Elvina Melinda ${ }^{1}$, N. Vinky Rahman ${ }^{2}$ \\ 1,2 Jurusan Arsitektur, Fakultas Teknik, Universitas Sumatera Utara \\ Jl. Perpustakaan St. J07 Building, Medan, 20155, Indonesia \\ *Email: elvinamelinda17@yahoo.com \\ Diterima: 2 Juni 2019 Direvisi: 27 Juni 2019 Online: 26 Juli 2019
}

\begin{abstract}
Tuktuk Siadong located on Samosir Island has amazing natural potential and cultural characteristics that make Tuktuk one of the favorite destinations of tourists. To fulfill the growth and needs of tourists in Tuktuk anaccommodation in the form of a Resort Hotel is needed. This design begins with a literature study and is followed by a field survey to produce the data needed ina design concept. These concepts produced a Resort Hotel design themed Neo-Vernacular Architecture that developed the basic principles of Batak Toba architecture and applied them in design. Resort hotels that are designed to be lodging accommodations that have supporting facilities to serve tourists who come.
\end{abstract}

Keywords: Batak Toba,neo-vernacular, resort hotel, tourism.

\section{INTRODUCTION}

Tuktuk is one of the tours on Samosir Island. Tuktuk has the natural potential that is favored, namely Lake Toba. In addition to its natural potential, the culture found in the Tuktuk area is also an attraction for tourists to visit. A distinctive cultural feature in this Tuktuk area is the Batak Toba. This characteristic can be enjoyed through the traditions of the community to the architecture of buildings in the Tuktuk region. As the number of tourists increases and supports the government's target of tourism development, the need to provide accommodation and facilities that can satisfy, increase understanding and appreciation of the area to tourists.

To fulfill the tourist in Tuktuk area accommodation is needed in the form of resort hotels. Resort hotels are a tourist attraction or recreational places where visitors come to enjoy the natural potential that exists. This resort hotel will later apply the existing culture by combining it with new aspects to have its selling value. The basic principles in Batak Toba architecture will be applied in the form of mass resort hotels. The application of this cultural element is to maintain the identity of the place and maintain the traditional values that have very well maintained. The identity of the place can add new knowledge and improve the quality of tourist activities (Ginting \& Wahid 2014).

In general,hotels are places that provide accommodation and services for its users. The resort is a place to stay that has a variety of facilities used by tourists for leisure activities, sports and traveling while enjoying the natural beauty that exists surrounding the resort. Based on the study, resort hotels can be defined as an accommodation facility which is located in a tourist area that has special facilities where visitors come to enjoy their natural potential (Pendit, 1999).

Resort hotels have fourcharacteristics that distinguish them from other types of hotels; there are a market segment, location, facilities, and architecture and atmosphere. For the market segment, target visitors are tourists who aim to vacation, have fun, and forget the daily work routine in the tourist area. In terms of location, generally, hotel resorts are located in places that have good tourism potential, for example, places with beautiful natural scenery such as beaches, mountains, river banks, or lakeside.At resort hotels, the facilities available are public facilities such as accommodation, service, relaxation. Besides, additional facilities are available by utilizing the natural wealth 
available on the site. For Architecture and atmosphere; resort hotel tourists are more likely to choose the appearance of buildings with natural or traditional themes with interior decoration motifs that are ethnic and outdoor with ethnic touches.

Neo-vernacular architecture is an application of existing architectural elements, the purpose of preserving local elements that have been formed empirically by a tradition which then undergoes little or more renewal towards a more modern or advanced work without ignoring local traditional values. In principle, Neo-Vernacular Architecture is Vernacular Architecture which undergoes renewal into a more modern or advanced work without ignoring local tradition values. The link between the form and meaning of architecture in Vernacular Architecture on culture must complement each other.

\section{METHOD}

The methodology in the case of this project began with the selection of site locations based on the Urban Planning in Simanindo District. The next method is collecting data by collecting various literature studies, field surveys by making direct observations to obtain data and find out the condition of selected locations, as well as comparative studies by searching for data from written sources on similar projects.

The design concept approach is the next step after the data collection method. Determination of this design concept is carried out by analyzing the data obtained from the results of regional observation studies and synthesis which is a merging phase of data from field sources and literature. After obtaining and analyzing all data, the author connects the results of the analysis with the theme that is used, namely neo vernacular architecture. A final stage is a design approach which is the conclusion of the synthesis process which is translated into a design in the form of a design drawing.

\section{RESULTS AND DISCUSSION}

Based on the related literature, the location of this resort hotel project is on the coast of Lake Toba. This is to exploit the natural potential as the main attraction of tourists to come to visit (Figure 1).

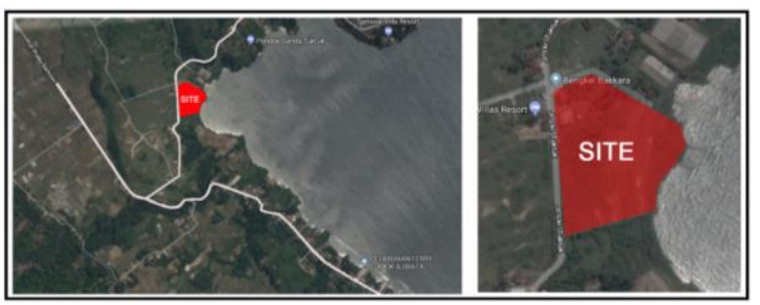

Figure 1. Location Map

The design location must be by the characteristics of a resort hotel where visitors come to enjoy the natural potential that exists. The design location was chosen based on the Urban Planning in Simanindo District. Based on Urban Planning in Simanindo District for 2017 2037, the project location falls into the category of Sub Block BWP IV with the function of trade allotment and souvenir and tourism services.

\section{Basic Concept}

This basic concept of the "Resort Hotel Design in Tuktuk" project interprets the application of neo-vernacular architecture. Elements that are applied/ transformed in addition to physical elements but also nonphysical elements such as cultural values, beliefs, layout, and others into building forms and site designs so that it can still preserve local culture with layers of modernization.

\section{The Design Concept of the Outer Space}

Zones on the site are divided into 3 zones, namely public zones, private zones, and service zones. In the public zone consists of the main entrance, parking space, and recreational facilities. The placement of public zones is at a strategic part beside the main road because the visitors who come will be more efficient and can access them directly (Figure 2). 


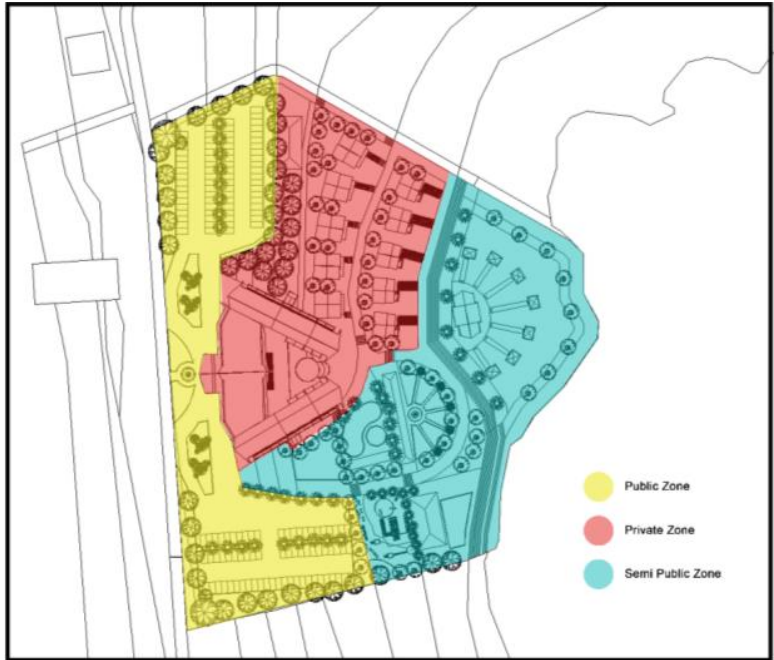

Figure 2. Site Zoning

Private zones are located in the middle to provide more privacy for hotel visitors. This zone includes the mass of hotels and resorts. The selection of the location in the middle of the site aims to let the main building has direct access to all the facilities provided in the resort hotel environment that is designed (Figure 3).

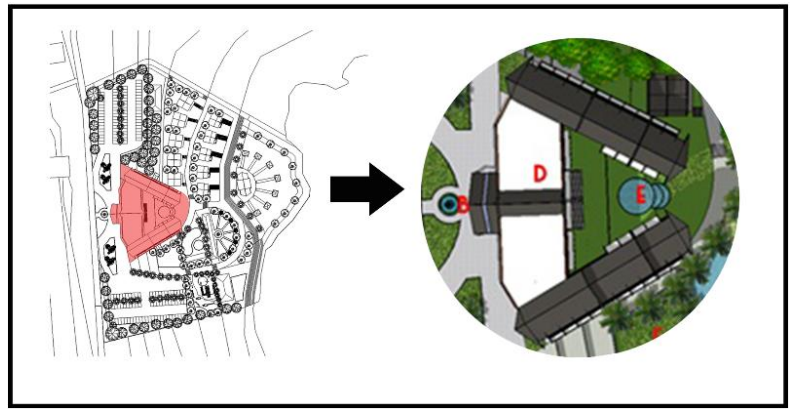

Figure 3. Laying the Mass of the Main Building

The mass resort area is located not far from the mass of the hotel. It is aimed at the tourists who stay at the resort can easily access to enjoy the facilities available at the hotel. The compilation of the mass of these cottages according to the pattern of settlement of the Batak Toba community (Figure 4 and 5).

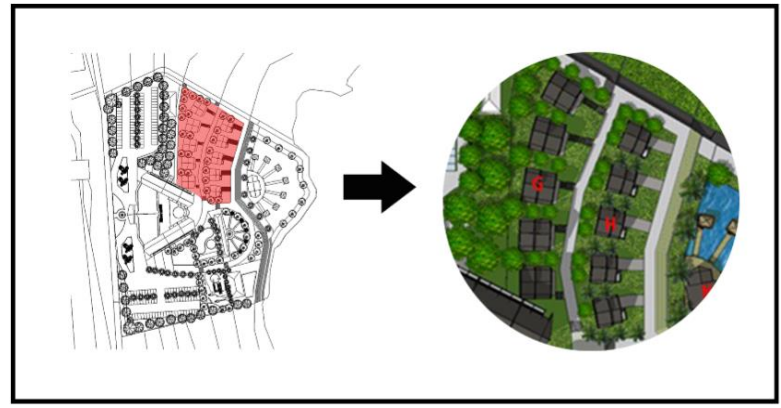

Figure 4. Laying the Mass of the Cottages

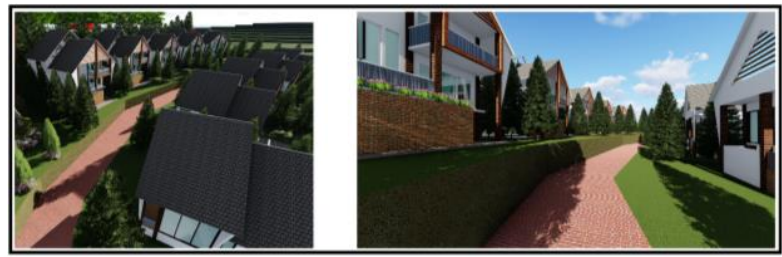

Figure 5. Cottage Area

The semi-public zone is on the side of the site that has more selling value because this zone supports the activities of visitors who stay or not stay overnight. In this area, there are supporting facilities such as retail area, swimming pool, children's play area, water play area, waterfront, and floating restaurant.One of the interesting things in the design of this Resort Hotel is the area of a floating restaurant. In this area, visitors can enjoy a meal that is surrounded by water with a treat of the beauty of Lake Toba and conduct swimming activities with a different atmosphere (Figure 6 and 7).

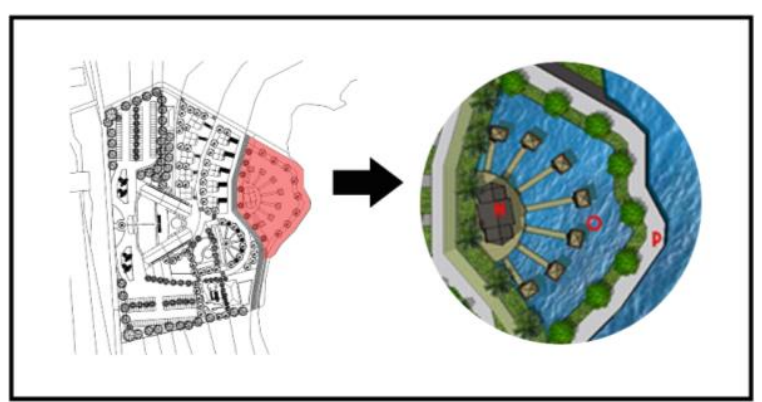

Figure 6. Laying the Area of Floating Restaurant 


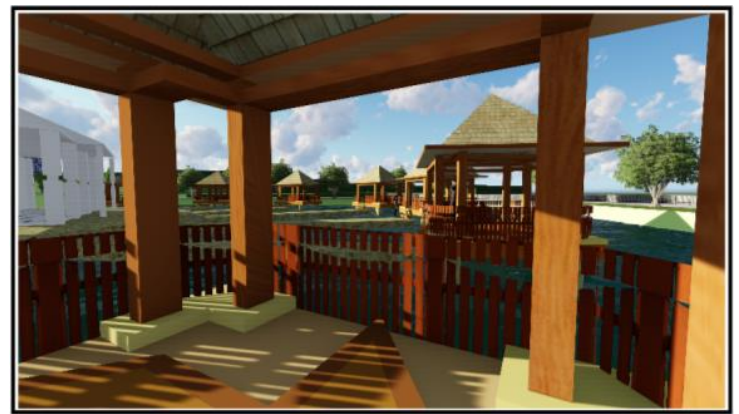

Figure 7. Area of Floating Restaurant

The design at the waterfront area along Lake Toba is as a recreation area, viewpoint, and also a sports area for visitors. In this area, there are also facilities for playing water such as banana boat, boat tour, jet ski, and canoeing. Floating restaurants adjacent to the waterfront area, where the main view while in this floating restaurant is Lake Toba. In this area, visitors can enjoy a meal surrounded by water and swim in a different atmosphere.

\section{Mass Concept of the Hotels}

The design of the mass of the hotels came from the traditional house of Batak Toba which then transformed. The roof becomes an important element in the formation of this resort hotel mass. The front facade of the main building planned as seen in the Batak traditional house (Bolon house) with the concept of a house on stilts only it is modified (Figure 8).

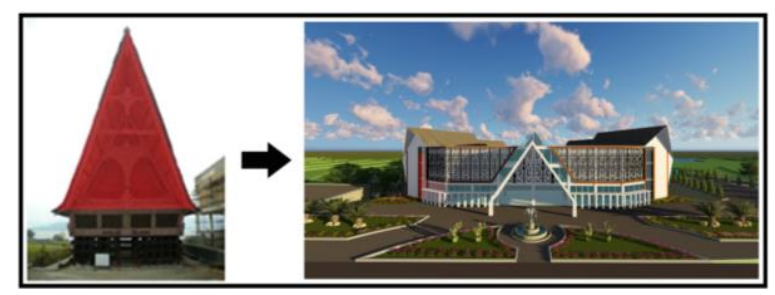

Figure 8. Mass of the Hotel

One characteristic of Batak Toba house is its large and tall shape. Large and high construction made the appearance of the Batak Toba house seem grand and authoritative. The Batak Toba house seems heavy, well established, and permanent due to the perception of large and many pillars (Wahid \& Alamsyah, 2013). The traditional house of Batak Toba is divided into three parts (Banua Trinity), namely Banua Toru (under the earth) for the foot of the house, Banua Tonga (world) for the housing body, and Banua Ginjang(sky) for the roof of the house.

The division of the Banua Trinity is remained visible but experiencing changes in its function. The high and large roof parts are still functions as a roof in the design. The roof shape of the traditional house of Batak Toba that curved on its upper part has transformed into a straight line according to the transformation theory by Laseau (1982), namely the transformation of geometry which is a change in geometrical shape with the same building components and spatial functions. The roof of a traditional house of Batak Toba has applied to the mass of the hotel namely the roof formation that extends and pointed forward.

In the body part of the house is used as a hotel room occupancy. On the part of the body (wall), the use of a sloping wall in traditional houses of Batak Toba in design is as sloping part of the balcony. For the foot part of the house is used as an outdoor restaurant area. After that, the mass of the building is divided into three sections vertically. Then each part is lowered following the contour height (Figure 9).

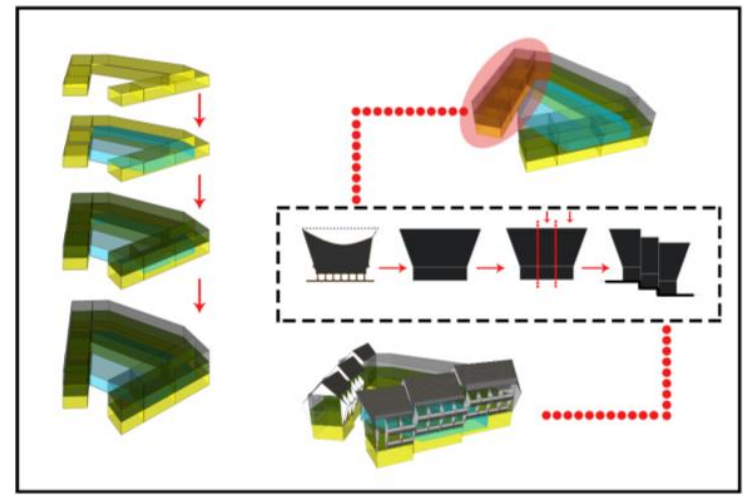

Figure 9. Arrangement of the Mass of the Hotel

\section{Mass Concept of the Cottages}

The basic form of cottages still takes from the formation of traditional house of BatakToba, namely the Bolon House. The principle used remains Banua Trinity, namely Banua Toru (under the earth) for the foot of the house, Banua Tonga (world) for the body of the house, and Banua Ginjang (sky) for the roof of the house. In the design of cottages, large and tall triangular body parts and roofs are used as a residence, whereas the legs that are under the 
wall are used as swimming pool areas (Figure 10).

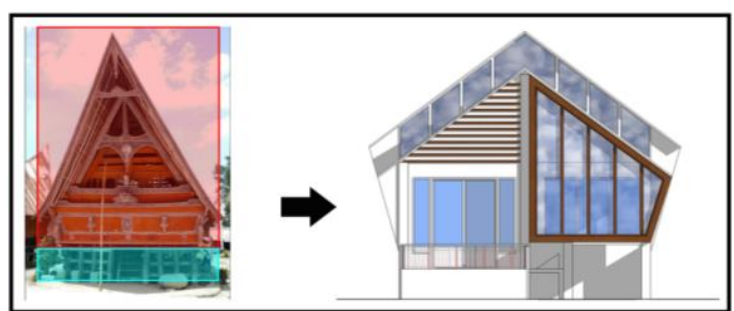

Figure 10. An arrangement of the Mass of the Cottage

\section{Structure Concept}

In a hotel building, the structure used is a rigid frame structure, which canwithstand the force in a vertical and horizontal direction stably. In the main building, the mass of the hotel, the foundation used is a pile with reinforced concrete material, so that it can withstand the weight of the building structure well and also has a construction process that does not damage the soil conditions on the design site with contoured conditions. Whereas in cottages and building facilities supporting resorts, the foundation used is a continuous foundation (Figure 11 and 12).

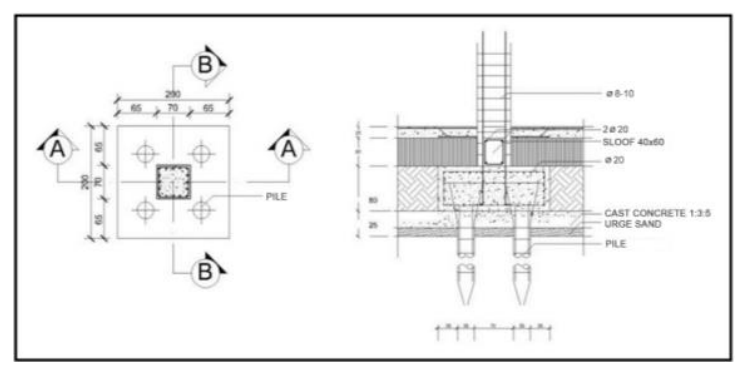

Figure 11. Detail of Pile Foundation

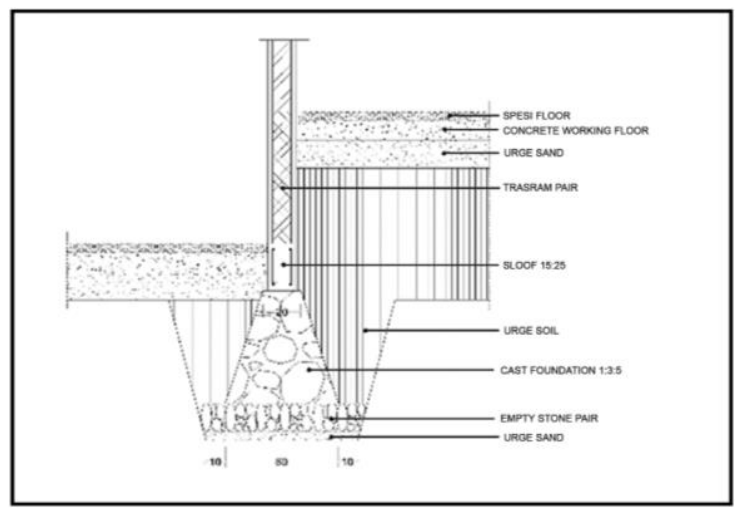

Figure 12. Details of Continuous Foundation

On the roof of the main building, the mass of hotels and cottages uses a lightweight steel roof structure to support the roof which is quite high. The selection of this structure because it can be adapted to the transformation from the roof shape of the traditional house of Batak Toba. Meanwhile, for the roof cover, the material used is the bitumen roof.

\section{Utility Concept}

The most prominent utility system in buildings in the tropics is air regulation. Usually, the building function that plays a role in accommodating community activities uses mechanical air regulation such as the use of air conditioning. With the existence of the air conditioning, the people in the building feel comfortable room temperature. However, considering the weather at the design site, the use of air conditioning is only used in semipublic and private spaces such as multifunction rooms, offices, and rooms. Whereas in the public area using natural air conditioning is produced by applying a large number of openings in the building.

\section{CONCLUSION}

The design of the Resort Hotel located on Jl. Lingkar Tuktuk, Tuktuk Siadong, Simanindo, Samosir are accommodation facilities to fulfill the growth and needs of tourism activities on Samosir Island. In designing this Resort Hotel, the application of the Neo Vernacular Architecture theme is very precisely applied to suit the context of the surrounding environment. The application of this cultural element is to maintain the identity of the place and maintain the traditional values that have very well maintained. Elements that are applied/ transformed in addition to physical elements but also non-physical elements such as cultural values, beliefs, layout, and others in the form of buildings and site design in the layer of modernization. This can be seen from the mass form of hotels and resorts that takes the transformation process from the traditional house of Batak Toba. The division of the Banua Trinity remains visible but changes in its function. The roof shape of the Bolon House that extends and pointed forward and curved has transformed into a straight on the upper part. Potential and problems in the design location are applied to the mass arrangement of supporting facilities and their application to buildings. 


\section{Acknowledgment}

This research is the result of the study of two authors who work together to implement the transformation of traditional Batak Toba architecture in the design of resort hotels in Tuktuk Siadong. The issue of increasing the number of tourists to the Tuktuk Siadong tourist area is an important issue at this time. Researchers hope this project can be input to the government to increase tourism in the tourist area of Tuktuk Siadong, Samosir North Sumatra.

\section{REFERENCE}

Ginting, Nurlisa \& Julaihi Wahid (2014) Exploring Identity's Aspect of Continuity of Urban Heritage Tourism.

Pendit, Nyoman S. (1999) Ilmu Pariwisata. Jakarta: Akademi Pariwisata Trisaksi.

Wahid, J \& Alamsyah, Bhakti (2013) Arsitektur \& Sosial Budaya Sumatera Utara. Yogyakarta: Graha Ilmu. 